\title{
The Management of Beginning Literacy for Children with Special Needs in Inclusive School
}

\author{
Sujarwanto, Yuliyati, Yatim Riyanto, Budiyanto, Muhammad Nurul Ashar \\ Faculty of Education \\ Universitas Negeri Surabaya \\ Surabaya, Indonesia \\ sujarwanto@unesa.ac.id
}

\begin{abstract}
This study aims to describe the implementation of the management functions including: planning, organizing, implementing, and evaluating in the development of literacy, especially in the beginning literacy in inclusive school which was focussed on: school literacy management by principal, learning process in inclusive class or resource class, also facilities support for beginning literacy. Qualitative approach with the multi-case design and Stake procedure were used. The study was held in SDN (Public Elementary School) Klampis-426 Surabaya. The result of this study showed that the function of literacy management according to GLS (School Literacy Movement) was good enough as the effect form the strong power performed by principals, in addition the management of beginning literacy in inclusive class was adequate by implementing collaborative principles, resource room and facilities were good enough, but on the other hand special class was not good enough.
\end{abstract}

Keywords-Management; Beginning Literacy; Children with Special Needs; Inclusive School

\section{INTRODUCTION}

Inclusive education and literacy become the trend of the 21 st century in which until today the topics of research and academic development are mainly many related to that issues. In Indonesia, the implementation of inclusive Education has a strong foundation namely The Law of Indonesia's National Education System No. 20/2003 Article 5 Clause 1 and Indonesia's Ministry of Education Regulation No. 70/2009 Article 1. Currently, inclusive education is growing rapidly, almost all of the city/district have organized inclusive education. Basic Education Data shows that there are currently 31,724 inclusive schools spread across the region in Indonesia. In more details, the level of primary school as many as 23,195 schools, junior high school as many as 5660 schools and senior high school as many as 2869 schools, "Of the number of schools, there are 159,002 children with special needs who have been served in inclusive school " (Dapodik (Educational Main Data, 2017)

Success or failure of beginning literacy development in inclusive school depending on the implementation of management functions, including: planning, organizing, executing, and evaluation in led by the principal and the implementation of learning management by the inclusive classroom teacher, special education teacher, and its supporting factors.

Beginning literacy (early stage of reading and writing ) in inclusive schools is interesting to be studied because in general children with special needs experienced this beginning literacy problem. Drummond (2009) stated more than 10 million students had beginning literacy difficulties. In fact, the beginning literacy must be mastered by students because it is the basic competence of mastery of academic development information and learning tools. Currently, Applied Curriculum 13 demands mastery of beginning literacy skills in the class.

The basic problem of children with special needs in beginning literacy development is rooted in low phonological and phonemic awareness resulting in low beginning reading and writing skills. Thus for that reason, it is necessary to develop an beginning literacy development that is appropriate to the characteristics of students in inclusive schools because according to Drummond (2009) 90-95\% students with special needs who experience reading problems will succeed if they study hard with strategies and help alongside effective learning management according to their needs of successful learning. In other words, effective beginning literacy management is needed to encourage all students with special needs to be successful.

The purpose of this study was to explore the practice of school management and classroom management in developing the beginning literacy of the children with special needs in inclusive schools focused on early literacy learning in the lower classes and special classes / resource room, including: (1) the role of principals in literacy management; (2) early literacy learning management in inclusive class (3) beginning literacy management in special classroom / resource room (special education teacher); (4) support of beginning literacy management (infrastructure).

\section{METHOD}

The template is used to format your paper and style the text. All margins, column widths, line spaces, and text fonts are prescribed; please do not alter them. You may note peculiarities. For example, the head margin in this template measures proportionately more than is customary. This measurement and others are deliberate, using specifications 
that anticipate your paper as one part of the entire proceedings, and not as an independent document. Please do not revise any of the current designations.

A descriptive qualitative approach was used to explore the phenomena and facts of beginning literacy learning management applied in inclusive schools with accurate interpretation. The multi-case design as described (Stake, 2005; Yin, 2009, Cresswell, 2013) was implemented because it was assumed that the investigation of a number of cases results in a more intact and profound understanding and allows to observe a variety of processes and products that will result in better generalizations. Research location was inclusive school Klampis Ngasem Surabaya. This school was chosen because it can be categorized as one of the pioneers of inclusive education in East Java province, it also has a number of children with special needs which was more than 60 students, there are also the special education teachers and psychologist who have gained some cultural literacy award.

The multi-case design implementation process was (1) determining topic and case limitation, (2) selecting phenomenon / theme / research issue, (3) determining data type and data collection technique, (4) doing triangulation, (5) analyzing and interpreting data, and (6) establish and determine what matters for the generalization decision of case findings. The participants of this research were including: 9 low-grade regular teachers, 6 special education teachers, 1 principal, and 2 librarians. Data were collected by in-depth interview techniques, participatory observation, field notes, recordings (audio/ video), and document scrutiny. Then data were analyzed by interactive flow data (Milles \& Huberman, 2015) and multipurpose techniques applied analytical procedures including: data reduction, data display, and conclusion drawing/verification.

\section{RESUlT AND DISCUSSION}

\section{A. Result}

The results of the research indicate that: (1) the role of the principal in the management of literacy has strong-power, both in the aspect of teacher-student and staff with high motivation, strict administration, library management with various activities and literacy activities, alongside with physical facilities which seen at joglo home in the schoolyard and literacy posters, won literacy awards both obtained by schools or students, as well as a lobbying development plan for shared reading activities; (2) learning of beginning literacy in the classroom (inclusive), generally quite adequate. Success depends entirely on the regular teacher's understanding of the comprehensive elements of successful literacy learning (literacy learning components, balance areas, tools and strategies, and assessment), and management of learning activities $(5 \mathrm{~T}+\mathrm{A}$ :Time, Task, Text, Talk, Teaching, + Assessment); creativity of teachers in managing and developing the means of class literate. In this case generally not fully understood. The learning of children with special needs in the inclusive class is sufficient, but not yet maximal, especially the means of learning, the supplement book for children with special needs that provides access to diversity according to the characteristics of children with special needs has not resulted in teachers teaching with conventional strategy; (3) the description of beginning literacy learning management in a special class and the source room of public elementary school Klampis includes (a) $72 \mathrm{crew}$; (b) in line with the policy of the Educational Bureau in 2014-2017 the number of special education teacher is four persons; (c) children with special needs received a mean of 11 , a maximum of 12 children with special needs for 3 study groups (d) implementing a specialinclusive classroom / transitional-classroom inclusive learning service (special class with pool out); (e) individualized and chalical learning for each crew, (f) special education teacher is responsible for special classes and transition classes by applying the learning sessions according to the students' needs (class sessions, therapy sessions) flexible with time distribution according to student disabilities (heavy, moderate) ; less literacy learning has not been effectively implemented. (4) literacy management support for schools is generally adequate to support GLS (school literacy movement) implementation. The description is (a) adequate library facilities equipped with library facilities, book collection, reading room, circulation table, bookshelves, cupboards, motivational posters, and adequate management. Library programs related to curriculum, parent involvement, and education office Program. (b) facilities in the classroom. Inadequate classroom infrastructure; varied classroom facilities (adequate and inadequate); the utilization of facilities has been good but not maximized, effective literacy learning management has not been understood, so the utilization of facilities has not been maximized. Suggestions need to improve the management of beginning literacy learning of children with special needs, especially management in inclusion class, special class, and resource room. Procurement, management, and utilization of initial litter learning facilities for children with special needs that support PAKEM (active, creative, and enjoyable learning) need to be facilitated by either the principal's teacher or principal.

\section{B. Discussion}

1) The role of principal in beginning literacy learning management

The first finding regarding the role of principal in literacy learning management was really appropriate in its implementation. Particularly, the principal role to plan, organize, implement, and evaluate the practice of literacy supporters or GLS successfully. Every 15 minutes before learning starts, students should read several books is applied according to the Regulation of the Indonesia's Minister of Education and Culture No. 23 of 2015. (Indonesia's Ministry of Education and Culture, 2015).

The second findings can be found in the vision, mission and the goals which are carried out in daily reading time and library visits. This shows the planning and organizational aspects documented and supported by the GLS (implementation) activities supported by adequate facilities with posters displayed in public spaces (schoolyard) as well as in the classroom and the aisle of this class support the development of beginning literacy for children with special 
needs because students are accustomed to reading, all friends read and there are literacy volunteers in each class who encourage and motivate friends, there are companion teachers as well as librarians who are planned, organized, implemented, and evaluated shows the function of management goes well despite the obstacles that can be overcome by subordinates well. This is in accordance with the demands of the development of GLS culture requires the structuring of a rich environment of literacy (Indonesia's Ministry of Education and Culture, 2016)

The success of this findings of the three principals in the management of school literacy goes well, strict discipline, high performance demands indeed produce good results and visible achievement. But some teachers and staff show complaints of distressed feelings due to these high demands. According to Hadari Nawawi [1] This style of leadership includes the archetype of the three styles of leadership attach importance to the results that can be achieved in order to realize the goals of groups or organizations.

\section{2) Beginning literacy learning management in inclusive class}

The first finding of beginning literacy management in inclusive classes showed that all aspects of management are adequate enough, especially in terms of lesson plan. As Combs statement (in Andang, 2014: 24), educational planning is a rational application of systematic analysis of educational development processes with the aim of making education more effective and efficient as needed. Especially with the implementation of the curriculum 2013. Referring to both makes it easier for teachers to design their lessons. The weakness of teachers depends on the student book which resulted in less creative teachers in developing language skills. Though Curriculum 13 textile / integrative thematic curriculum features communicative (read-write, listeningtalking, observing-communicating) aspects that must be well developed (Check K3 and K4). To maximize language development as the main support of science literacy, mathematical literacy and literacy reading as well as problem solving as required in the PISA study (R \& D Indonesia's Ministry of Education and Culture, 2013) required a learning approach that can develop students' reading and writing skills as well as develop other language skills (reading and writing, listening and speaking, viewing/observing and visual presentation / communicating). Learning is guided by the Master Book and Student Book. Referring to both makes it easier for teachers to design their lessons. A balanced approach is effective for the development of learning for both regular and crew students (USAID Prioritas, 2014, Yuliyati, 2015).

The findings of the three beginning literacy lessons in the inclusive classes were conducted collaboratively between regular teachers and special education teacher. The purpose of the content/materials, methods, and evaluation modified according to children with special need level of ability. Low children with special need understanding of the material being studied in the inclusion class is followed up in a special class. This is in accordance with the opinion of Special Education Department Unesa Team (2012) which state that the modification means changing to conform. The curriculum for children with special need based on the curriculum of regular students is changed to suit the students ' special needs. children with special need learns with curriculum according to their needs and abilities. Modifications can be applied to four main components of learning: objectives, materials, processes, and evaluations.

The findings of the four teachers' understanding of the beginning effective literacy learning are still inadequate. Teachers have not yet perfected facilities developed by Indonesia's Ministry of Education and Culture with Usaid Priority (2014). Whereas every teacher is required to improve their competence include personality, pedagogical, professional, and social competence (National Education Department, 2005). According to Daryanto [2] the causes of low professionalism among teachers are still many teachers who do not pursue their profession as a whole, there is no professional standard of teachers as developed countries, graduated teachers from universities of origin, and lack of teacher motivation in improving the quality of self when the facilities are available teachers need to be proactive.

The fifth evaluation findings are planned and implemented in each learning unit. Referring to K13 there is a self-evaluation that must be filled by the students. For special education teacher self-evaluation is adjusted and replenishment is guided by the teacher. This ni aligned with the opinions Sunardi \& Sunaryo [3] that in the evaluation of: (1) need to adjust the way, the timing and content of curriculum, (2) refers to the results of the assessment, (3) consider the use of Assessment Reference Self, (3) are held in routine (4) communicating the results to parents. [3]

3) Beginning literacy learning management in special classroom/resource room (special education center)

The first finding in this aspects shows that planning, organizing, and implementation, and evaluation have not been adapted to PAKEM learning as stated in the mission and objectives of the school. Lesson planning is limited to modification of students' level of ability. Learning according to level of ability with conventional strategy, imitating, copying. According to Indrawati the PAKEM concepts are including (1) Students engage in various activities that develop their understanding and abilities with an emphasis on learning through doing. (2) Teacher uses a variety of tools and various ways of generating passion, including using the environment as a learning resource to make learning interesting, fun and suitable for students. (3) Teacher organizes the class by displaying more interesting books and study materials and provides a "reading corner"; (4) Teacher apply a more cooperative and interactive way of teaching, including group learning. (5) Teacher encourages students to find their own way in solving a problem, to express their ideas 
and engage students in creating the school environment (Indrawati, 2005).

The second finding shows that class arrangement is not sufficient. One small class for the two study groups means a good grade requirements ratio as specified by Indonesia's ministry of education is not implemented.

4) Support of beginning literacy learning management (infrastructure)

The first findings of the beginning literacy on infrastructure at public elementary school Klampis Ngasem I246 is adequate. This is in accordance with Minister of Man power Regulation No. 24/2007 on Standard of Facilities and Infrastructure for Primary Schools / Elementary School, that each educational unit is required to have infrastructure covering land, classrooms, leadership room, educator room, administrative room, library room, laboratory room, workshop room, production unit room, canteen room, power and service installation, gymnasium, place of worship, playground, creative place, and other space / place which are needed to support regular learning process and sustainable.

The findings of the two beginning literacy learning media in the inclusive class, an adequate class of several classes are sufficient for the minimum standards. However, in special class is not enough. In the resource room is sufficient for the minimum stand-ard, but not yet complete. For the fulfillment of all the needs of children with special needs has not been realized this is in line with Sunaryo \& Sunaryo who analyze [3] that the limitations of school facilities, the implementation of learning has not used the media, resources, and environment that vary according to the needs of children. According Yuliati \& Sujarwanto (2016) is generally in learning to read and write case is primarily the unavailability of a class library, the arrangement of a classroom environment that is rich in literacy learning, the class as a learning resource, availability of media and material support for the development of the literacy skill, for example, exposure to books interesting books, visuals, word cards, word walls, literacy centers and so on. Big Book is one of the media in reading learning with shared reading approach or reading together. Holdaway was the first to create Big Book as a way of making Big Book a model that students could see (Fisher, et al: 2008). Holdway [4]mentions three characteristics of successful reading learning are: (1) The selected book should be the book favored by the students, (2) The student should be able to see for himself the book, and (3) The teacher should read the story in an interesting and enthusiastic way.

\section{CONCLUSION}

The management of school literacy related to the initial literacy learning that has been played by the principal, includes aspects of planning, organizing, implementation, and evaluation goes well with organized management, strong power, controlled, motivated and discipline, and good performance demands. While in the beginning literacy learning management in inclusive classes played by class teachers and special education teachers showed that planning, organizing, implementation, and evaluation aspects were collaborative between class teachers and special education teachers is sufficient. Moreover learning management in a special class for students who are not yet academically ready played by special education teachers shows that the aspects of planning, organizing, implementation, and evaluation are sufficient in the sense that the service is limited to children with special needs level of ability and the implementation PAKEM is not maximal yet. Furthermore, in terms of infrastructure, the class has not met the infrastructure standard. Although, the beginning literacy learning of children with special needs is supported by school literacy infrastructure, especially for GLS activities.

\section{RECOMMENDATION}

A good GLS program support for early literacy development management needs to be improved with posters that motivate children with special need. Low-grade teachers need to master effective initial literacy management, training, or workshops to understand this material needs to be programmed, organized. implemented and implemented in each teacher's classroom. This requires funds. The principal needs to seek funding for the improvement of early literacy learning. Teachers of the class and special education teacher should always improve their professionals by always increasing their knowledge. In the field of beginning literacy learning, effective initial literacy learning management needs to be studied and applied in the classroom in order for PAKEM missions to be realized. The Kemendikbud + USAID Prioritas web facility is useful for initial literacy improvement for children with special need and regular students.

\section{REFERENCES}

[1] R. E. Stake, Multiple case study analysis. Guilford Press, 2013.

[2] R. K. Yin, "Case study research: Design and methods (applied social research methods)," London Singapore Sage, 2009.

[3] J. W. Creswell and V. L. P. Clark, Designing and conducting mixed methods research. Sage publications, 2017.

[4] Torch, Principal Management and Leadership. Yogyakarta: Ar-Ruzz Media, 2014.

[5] H. Hadari Nawawi and M. M. Hadari, "Kepemimpinan Yang Efektif," Cet. Ke-II. UGM. Yogyakarta, 1995.

[6] D. Daryanto, "Media pembelajaran: Peranannya sangat penting dalam mencapai tujuan pembelajaran," Yogyakarta Gaya Media, 2010.

[7] S. Sunardi and S. Sunaryo, "Manajemen Pendidikan Inklusif (Konsep, Kebijakan, dan Implementasinya)," JASSI ANAKKU, vol. 10, no. 2, pp. 184-200, 2016.

[8] D. Holdaway, The foundations of literacy, vol. 138. Ashton Scholastic Sydney, 1979. 